Creative Commons User License: CC BY-NC-ND

Abstracted by: EBSCOhost, Electronic Journals Service (EJS), Google Scholar, Journal Seek, Scientific Commons,

Food and Agricultural Organization (FAO), CABI and Scopus
Journal of Agricultural Extension

Vol. 23 (3) July, 2019

ISSN(e): 24086851; ISSN(Print); 1119944X

http://journal.aesonnigeria.org

http://www.ajol.info/index.php/iae

Email: editorinchief@aesonnigeria.org

\title{
Use of Information Communication Technologies among Agricultural Extension Officers in Lesotho
}

https://dx.doi.org/10.4314/jae.v23i3.4

Akintunde, Moruf Abiola. 0.

Department of Agricultural Economics and Extension, Northwest University, Mafikeng,

South Africa. Email: maakintunde@gmail.com; Phone: +26658865964.

Oladele, Oladimeji Idowu.

Department of Agricultural Economics and Extension, Northwest University, Mafikeng, South Africa. Email: oladele20002001@yahoo.com; Phone: +27786400564

\begin{abstract}
The study assessed the use of ICTs among public and private extension officers in Lesotho. A structured questionnaire was used to collect data from 86 public and 19 private extension officers. Data collected were analysed, using percentages, mean, and standard deviation, multiple regressions and t-test. Extension officers use ICT tools to obtain information on new technology (79.1\%), preservation of farm produce (79.1\%); time of planting crops $(75.6 \%)$, call attention of extension officers $(75.6 \%)$ and cultural practices (75.6\%). Serious constraints to the use of ICTs, as perceived by extension officers were: high cost of ICT (83.7\%); poor basic infrastructure (79.1\%); non-availability of technical personnel (72.1\%), failure of service (73.7\%) and non-availability of genuine parts. There is a strong relationship between access to information, residing within place of work, constraints, age awareness, type of extension and use of ICTs. There is also a significance differences in the use of ICTs between public and private extension officers. Policy makers should improve national e-readiness and make more ICT tools available and accessible to extension officers. Constraints of high cost, lack of ICT infrastructure and training of technical personnel should be dealt with.
\end{abstract}

Keywords: Use of ICTs, public extension, private extension, Lesotho

\section{Introduction}

Agriculture in Lesotho is mainly rural and characterised by low productivity due to obsolete farming systems and practices, challenge of accessing credit for commercial agriculture, weak rural infrastructure, constraining land tenure system, poor government rural development policy, poor implementation of viable policies, ineffective extension service and challenges of accessing markets for agricultural products. Face-to-face interactions are still considered the best method of effective communication, but the down side is that extension officers struggle to meet their clients in a timely and regular manner, particularly in countries where infrastructure, budgets and other factors severely limit service provision to rural people (USAID 2013). According to Bell (2015), both public and private extension services in developing countries face tremendous challenges to reach many and diverse 
Creative Commons User License: CC BY-NC-ND

Abstracted by: EBSCOhost, Electronic Journals Service (EJS), Google Scholar, Journal Seek, Scientific Commons,

Food and Agricultural Organization (FAO), CABI and Scopus
Journal of Agricultural Extension

Vol. 23 (3) July, 2019

ISSN(e): 24086851; ISSN(Print); 1119944X

http://journal.aesonnigeria.org

http://www.ajol.info/index.php/iae

Email: editorinchief@aesonnigeria.org

farmers that require their services. Reasons for this include small farms with limited resources, large number of farmers, poor infrastructure, high rate of illiteracy among farmers, extension skills of extension workers and poor funding of extension services. Most Basotho live in remote rural areas and engage in agricultural activities such as growing crops and rearing animals for their livelihoods (Qamar, 2014). This agricultural population is scattered all over the country on difficult terrains, making it a challenge for extension services reaching them. The application of ICTs can increase farmers' production capabilities and allow them to access timely information from extension workers in order to sustain their farming activities (Ajani, 2014).

The agricultural extension service in Lesotho has tried various approaches ranging from public, commodity, training and visits and farmer field schools. These have not been effective enough to enable extension reach out to all farmers, particularly those in mountainous areas, especially in winter. Extension workers have not taken full advantage of modern ICT tools, such as cell phones and the Internet to make their jobs more effective. They still use traditional extension methods of communication, which are no longer adequate in serving the purpose of disseminating time-bound research discoveries. As a result, huge spending on agriculture by the government and non-governmental organisations (NGOs) has not improved smallholder farming in these rural areas. According to the Food and Agriculture Organisation (FAO 2017), the Lesotho government spends $9 \%$ of its budget on social protection schemes, including agricultural subsidies, but there is no commensurate return on this investment. Improvement in the dissemination of information by the Department of Field Services of the Ministry of Agriculture and food Security (MAFS) will go a long way in contributing to improvement in agricultural production in rural areas.

The use of ICT is crucial if extension officers are to keep pace with the ever-increasing scientific discoveries from agricultural research stations and other sources. Adoption of various ICT tools could facilitate proper management of information processing and dissemination, thus increasing the speed and accuracy of dissemination of information than is currently the case. It will also alleviate the problem of low extension agent-farmer ratio experienced in Lesotho, where it stands around 1:600 (Tuoane, 2018, personal communication). Radio, television and print media that are already in use, can be made more effective, and ICTs such as mobile phones, e-mail, the Internet and social media, could be introduced to save time, money and labour.

The Lesotho Communication Authority (LCA) is the regulatory body that controls the communication sector in Lesotho. It achieves this through granting of licenses to operators, promotion of fair competition, approval of tariffs, management of radio frequency spectrum, protection of consumers and approval of terminals. There are two mobile phone service providers in Lesotho: Econet Telkom Lesotho (ETL) and Vodacom Lesotho (VCL). So far, VCL was leading the race with 1,448,925 subscribers nationwide in 2016, while ETL had 448,292 subscribers (Table 1). 
Creative Commons User License: CC BY-NC-ND

Abstracted by: EBSCOhost, Electronic Journals Service (EJS), Google Scholar, Journal Seek, Scientific Commons,

Food and Agricultural Organization (FAO), CABI and Scopus
Journal of Agricultural Extension

Vol. 23 (3) July, 2019

ISSN(e): 24086851; ISSN(Print); 1119944X

http://journal.aesonnigeria.org

http://www.ajol.info/index.php/iae

Email: editorinchief@aesonnigeria.org

Table 1: Mobile cellular phones operators and number of subscribers

\begin{tabular}{cccc}
\hline & \multicolumn{3}{c}{ Subscribers } \\
Operator & 2008 & 2012 & 2016 \\
\hline ETL† & 110500 & 126250 & 448292 \\
VCL* & 489000 & 543500 & 1448925 \\
TOTAL & 599500 & 669750 & 1897220 \\
\hline
\end{tabular}

†ETL: Econet Telkom Lesotho, ${ }^{*} \mathrm{VCL}$ : Vodacom Lesotho

Radio is still common among households, with $52.8 \%$ of households indicating that they have a radio. Radio density is much higher than that of all other devices used as about $53 \%$ of households own a radio (LCA, 2017). Thaba-Tseka, Mokhotlong and Quthing still have the lowest adoption of radio. Ownership of a Television set is lower than that of radio representing 30 households per 100 . Similarly, the share of households that own a television set in the three districts mentioned above remains low. Penetration of television stands at $29.47 \%$ and is higher than the density of household mobile phones, estimated at $16.5 \%$. Overall, the adoption pattern of radio and television among the districts was more or less similar (LCA, 2017).

Fixed-line tele-density in Lesotho is low as only 1.9 per 100 households has fixed-line connections (LCA, 2017). The use of fixed lines in some districts, such as Mokhotlong, Thaba-Tseka and Quthing is very low, with majority of residents in these places having no fixed-line connections. The estimated computer density is low, representing only 3 per 100 households. However, penetration of laptops is slightly higher than the density for computers at about $6 \%$. Most people who own laptops and computers live in Maseru. A small proportion of residents in Mokhotlong and Thaba-Tseka own laptops, while ownership of computers in Mokhotlong, Thaba-Tseka and Quthing is negligible. A disaggregation by gender of household-head shows that female-headed families are more likely than male-headed families to have ICT devices. However, male-headed households are more likely than female-headed households to have a mobile phone and a computer. Penetration of mobile phones is high but not fully utilised. Many rural-dwellers are not fully benefitting from mobile technology because they have not taken advantage of the full potential of such technology, for instance, mobile phone-based financial transactions are still very low (LCA, 2017). 
Creative Commons User License: CC BY-NC-ND

Abstracted by: EBSCOhost, Electronic Journals Service (EJS), Google Scholar, Journal Seek, Scientific Commons,

Food and Agricultural Organization (FAO), CABI and Scopus

http://eoi.citefactor.org/10.11226/v23i3
Journal of Agricultural Extension

Vol. 23 (3) July, 2019

ISSN(e): 24086851; ISSN(Print); 1119944X

http://journal.aesonnigeria.org

http://www.ajol.info/index.php/jae

Email: editorinchief@aesonnigeria.org

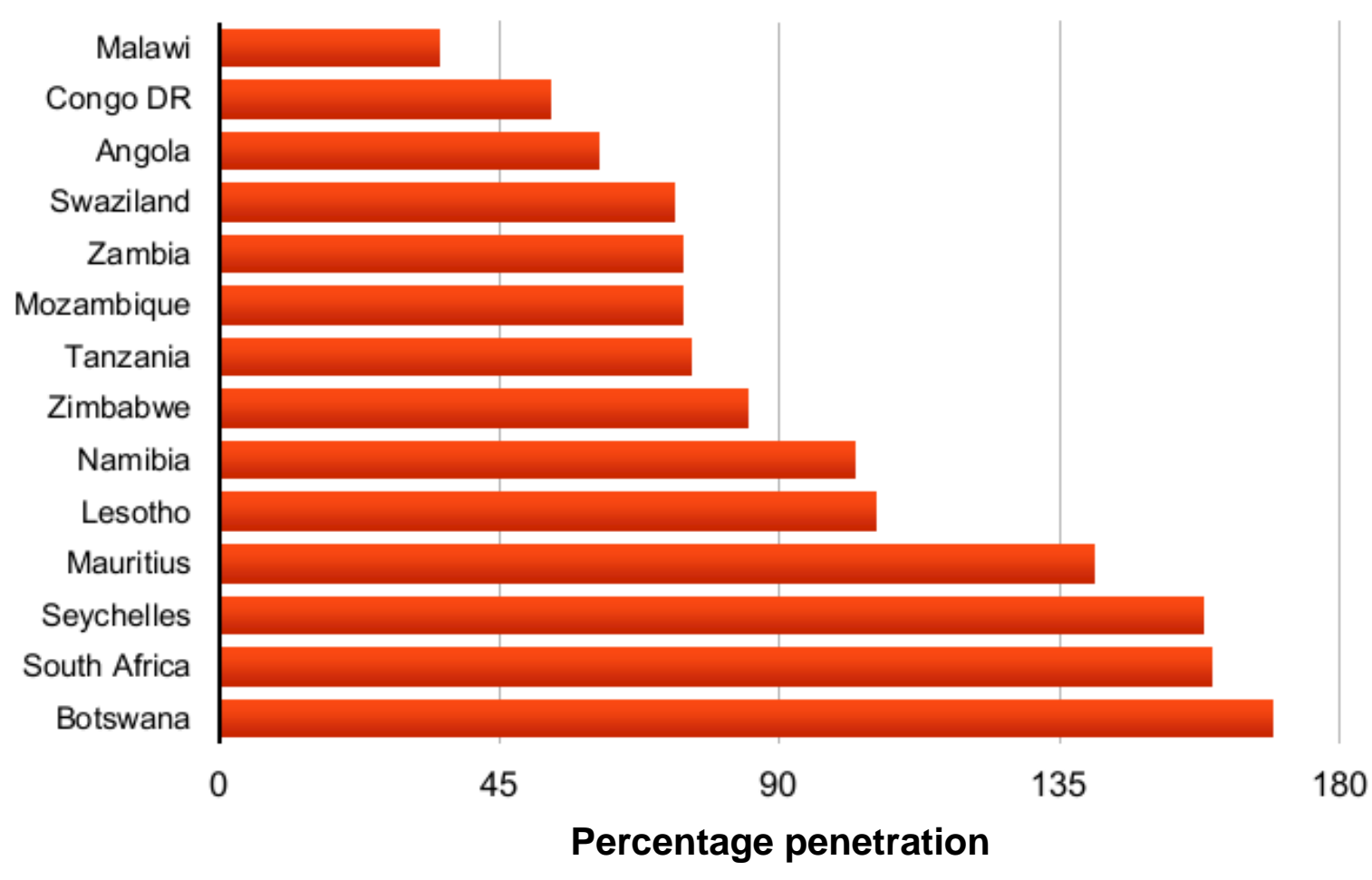

Figure 1: Penetration of mobile phones in SADC countries Source: ITU Statistics, 2016.

Access to mobile phone can improve the standard of living by reducing transaction and transport costs, providing information about prices or used for banking and health care. One of the contributing factors to the low level of usage of ICTs in Lesotho is that half of the number of households in the country have no access to electricity (LCA, 2017).

Access to broadband Internet in general, and mobile broadband in particular, is becoming increasingly important to national economies and the personal lives of users. As of 2016, about $11 \%$ of the world's population had access to fixed broadband. While $30 \%$ of developed countries had access to fixed broadband, only $8.2 \%$ of developing countries had access to it (ITU, 2016). However, while most low-income earners are not connected to fixed broadband, the introduction of mobile broadband services has the potential to reduce the digital divide and give the poor an opportunity to connect to the Internet. It is evident that in developing countries, adoption of broadband is slower in rural areas than was the case with adoption of mobile phones. According to ITU (2016), about $90 \%$ of the population in developed countries are connected to mobile broadband, while only $40.9 \%$ of the population in developing countries can access mobile broadband.

A household and individual survey conducted across 12 African countries in 2012 found that most people across African countries were accessing the Internet through their 
Creative Commons User License: CC BY-NC-ND

Abstracted by: EBSCOhost, Electronic Journals Service (EJS), Google Scholar, Journal Seek, Scientific Commons,

Food and Agricultural Organization (FAO), CABI and Scopus
Journal of Agricultural Extension

Vol. 23 (3) July, 2019

ISSN(e): 24086851; ISSN(Print); 1119944X

http://journal.aesonnigeria.org

http://www.ajol.info/index.php/iae

Email: editorinchief@aesonnigeria.org

mobile phones (Stork et al., 2013). The study reveals that the first point of access to the Internet by most Internet users, is the mobile phone. At the national level as well as across sexes, more than $80 \%$ of individuals indicated that they used their mobile phones to first gain access to the Internet. This is also the case in Lesotho.

The use of computers (desktop or laptop) is comparatively low. Over $80 \%$ of respondents stated that they had never used a computer before. The share of women who have never used a computer is higher at about $82 \%$ compared to men at $74.8 \%$. However, the figure can be considered high across both sexes. Of those who have used a computer before, a higher proportion (10.1\%) stated that they did so occasionally, while only $5.8 \%$ indicated that they used a computer daily (LCA, 2017).

ICT infrastructure in Lesotho is currently inadequate, with accessibility to telecommunication services representing about 3\% of the entire population for fixed land lines and just about 20\% for mobile phones (Maphephe et al., 2014). Furthermore, personal computers are mainly confined to urban cities and were estimated to be less than 30,000 in 2000. The Lesotho ICT policy provided guidance by allocating a range of responsibilities to role players: involving the Ministry of Communications to formulate policies and the Lesotho Communication Authority (LCA) to regulate operations in communication infrastructure (Maphephe, 2014). Despite Lesotho's poor ICT infrastructure, initiatives have been taken to promote access and usage of ICTs in educational institutions. This was done through two key projects as follows: The New Partnership for Africa's Development (NEPAD) e-schools demonstration project; and SchoolNet Lesotho. These projects aim to impact ICT skills and knowledge by providing education in schools through application of ICT and usage of the Internet (Qamar, 2014).

Generally, ICT tools can serve a complementary role to deliver and improve agricultural extension services and allow different stakeholders to interact across geographical barriers in real time. They can also dramatically improve access of farmers and intermediaries to information relevant to household productive agriculture and agribusiness. The level of awareness of ICTs, demographic characteristics of extension officers, constraints to the use of ICT, among other factors, were suspected to be responsible for reasons for Lesotho extension system not using modern ICT tools in its dissemination of agricultural information. 
Creative Commons User License: CC BY-NC-ND

Abstracted by: EBSCOhost, Electronic Journals Service (EJS),

Google Scholar, Journal Seek, Scientific Commons,

Food and Agricultural Organization (FAO), CABI and Scopus
Journal of Agricultural Extension

Vol. 23 (3) July, 2019

ISSN(e): 24086851; ISSN(Print); 1119944X

http://journal.aesonnigeria.org

http://www.ajol.info/index.php/iae

Email: editorinchief@aesonnigeria.org

\section{Objectives of the study}

The general objective of the study was to identify determinants of use of ICTs by public and private agricultural extension officers in Lesotho, while specific objectives include to:

- identify constraints to the use of ICT tools among agricultural extension officers; and

- determine the difference in the use of ICTs between public and private agricultural extension officers.

\section{Hypotheses of the study}

1) There is no significant relationship between respondents' demographic characteristics and use of ICT.

2) There is no significant difference in the use of ICT between public and private extension officers in Lesotho.

\section{Methodology}

The study was conducted in Lesotho. Lesotho is a country located between latitudes $28^{\circ} \mathrm{S}$ and $31^{\circ} \mathrm{S}$ of the equator and Longitudes $27^{\circ} \mathrm{E}$ and $30^{\circ} \mathrm{E}$ of the Greenwich Meridian (ClA, 2016). It is completely surrounded by the Republic of South Africa and covers about 30340 square kilometres, with highlands ranging between 1500 metres at its lowest level to $3 \mathbf{3 0 0}$ metres at its highest level. Lesotho's climate is semi-humid to semi-arid. Generally, it has warm wet summers and cold dry winters. The average annual rainfall varies from about $500 \mathrm{~mm}$ in western Lesotho and to over $1,000 \mathrm{~mm}$ in the mountains (Worth and Molomo, 2016).

The population of Lesotho was estimated at 2.1 million people (CIA Fact book, 2015), the majority of whom earn their livelihoods from agriculture. An estimated $85 \%$ of this population resides in the rural areas. The country's main products include beans, livestock, maize, sorghum and wheat, though the only agricultural exports are wool and mohair. Only about $10 \%$ of the country's land is suitable for agriculture and more than $80 \%$ of its people are engaged in subsistence farming (Lesotho Review, 2015).

The population of the study consisted of 310 public agricultural extension workers in the ten districts of Lesotho. However, only eight districts were able to participate in the study due to administrative challenges in two districts, reducing the population of public extension officers to 250. Private extension respondents were made up of extension officers from NGOs that were fully involved in agricultural extension services at the time of the study. Initially, there were 50 extension staff of non-governmental organisations (NGOs) that was targeted for the study, but the number dropped because some organisations pulled out of the study at the last minute. A total of 19 private extension officers from the following NGOs in Lesotho participated in the study: World Vision; SEND A COW; Rural Self-Help Development Association (RSDA); GROW; and Serumula Development Association (SDA). 
Creative Commons User License: CC BY-NC-ND

Abstracted by: EBSCOhost, Electronic Journals Service (EJS), Google Scholar, Journal Seek, Scientific Commons,

Food and Agricultural Organization (FAO), CABI and Scopus
Journal of Agricultural Extension

Vol. 23 (3) July, 2019

ISSN(e): 24086851; ISSN(Print); 1119944X

http://journal.aesonnigeria.org

http://www.ajol.info/index.php/iae

Email: editorinchief@aesonnigeria.org

An online Raosoft sampling engine was used to calculate the sample size of 152; a simple random sampling technique was then used to select 152 from a list of 250 at the Department of Field Services in Maseru. However, only 86 public extension officers were able to return completed questionnaires that were eventually analysed. All 19 private extension officers were selected because they were few in number, thus giving a total of 105 respondents for the study.

A structured questionnaire was designed based on related literature and objectives of the study, and used to collect data from respondents. Open and close-ended questions and items were used to solicit information from respondents. The instrument was content and face validated by three experts from the Department of Agricultural Economics and Extension, North-West University, Mafikeng Campus, South Africa. The instrument was then reviewed according to the suggestions of the experts. Reliability was determined by using the split-half technique. The statements were split into two halves on the basis of odd and even numbered statements and then administered to 20 respondents from the Department of Field Services (DFS), Maseru, who were not part of the actual study. Cronbach's alpha coefficient obtained from the two sets of scores was 0.79 , an indication that the instrument was reliable. Thakur et al. (2017) explained that the closer the value of Cronbach's alpha coefficient to 1, the higher the reliability.

Data collected were analysed using IBM-SPSS Statistics 22, with percentages,

frequencies and means. Significant relationship between respondents' demographic characteristics and use of ICT

was analysed using multiple regressions while the independent t-test was used to analyse significant difference in the use of ICT between public and private extension officers.

The following multiple regression model was used:

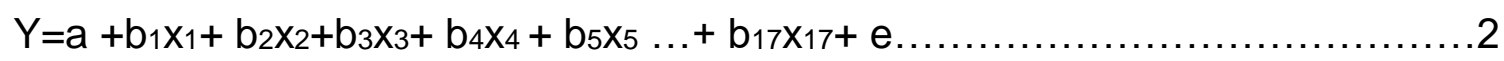

Where,

$\mathrm{Y}=$ use of ICT, that will be predicted or explained;

$\mathrm{a}=$ intercept;

$\mathrm{b}=$ regression coefficient for each independent variable;

$\mathrm{X}_{1}=$ e-readiness; $\mathrm{X}_{2}=$ residence of respondent; $\mathrm{X}_{3}=$ constraints to ICT use; $\mathrm{X}_{4}=$ job location; $X_{5}=$ means of mobility; $X_{6}=$ religion; $X_{7}=$ age; $X_{8}=$ gender; $X_{9}=$ no. of farmer groups covered; $X_{10}=$ access to information; $X_{11}=$ importance of ICT; $X_{12}=$ living in job area; $\mathrm{X}_{13}=$ accessibility to ICT; $\mathrm{X}_{14}=$ competence in ICT use; $\mathrm{X}_{15}=$ awareness of ICT; $\mathrm{X}_{16}$ $=$ availability of ICT; $\mathrm{X}_{17}=$ extension type.

$e=$ error 
Creative Commons User License: CC BY-NC-ND

Abstracted by: EBSCOhost, Electronic Journals Service (EJS),

Google Scholar, Journal Seek, Scientific Commons,

Food and Agricultural Organization (FAO), CABI and Scopus
Journal of Agricultural Extension

Vol. 23 (3) July, 2019

ISSN(e): 24086851; ISSN(Print); 1119944X

http://journal.aesonnigeria.org

http://www.ajol.info/index.php/iae

Email: editorinchief@aesonnigeria.org

\section{Results and Discussion}

\section{Determinants of Use of ICT Tools among Respondents}

Table 2 presents the results of regression analysis of the effects of independent variables on the use of ICT among public and private extension officers in the study area. The Table reveals that variation in the use of ICT by extension officers was explained by predictor variables. The value $F$ is 7.007 and $p<.05$, this shows a high level of correlation between the independent variables and use of ICT tools by extension officers. Six out seventeen independent variables were determinants of use of ICT tools by extension officers. Significant determinants were residing within place of work $(t=2.051 p \leq 0.05)$, constraints $(t=2.606 p \leq 0.05)$, age $(t=-2.931 p \leq 0.05)$, access to information $(t=5.023 p \leq 0.05)$, awareness $(\mathrm{t}=1.895 \mathrm{p} \leq 0.05)$ and type of extension $(\mathrm{t}=-1.876 \mathrm{p} \leq 0.05)$.

Residence of extension officers within the place of work had a significant positive impact on the use of information and communications technology by extension officers. This implies that a unit change in the residence of extension officers leads to $18.2 \%$ increase in the use of ICT tools. This means that living within the place of work will encourage extension officers to use ICT tools regularly.

Constraints to the use of ICT tools had a significant positive impact on the use of information and communications technology by extension officers. This implies that a unit change in constraints to the use of ICT tools leads to $19.9 \%$ increase in the use of ICT by respondents. This means that the fewer the constraints experienced by extension officers, the more frequent they use information and communications technology. Addressing constraints to the use of ICT will encourage more extension officers to use them in their personal and professional duties. Verma et al., (2014) also reported that government and non-government extension officers in India experience some challenges in the use of ICT at different levels. This confirms that constraints to the use of ICT in information dissemination by extension agents is worldwide, though it is more serious in some areas than others.

Age of extension officers had a highly significant negative impact on the use of information and communications technology. This implies that a unit increase in the age of extension officers leads to $23 \%$ decrease in the use of ICT tools. This means that the older the extension officers becomes, the less they are likely to use ICT in their work. This result is important because both public and private extension officers in Lesotho are relatively young, thus, they are likely to use ICTs to disseminate information to farmers. This is a welcome development because stakeholders can take advantage of the fact that young people are always in the forefront technological revolution (Meera and Meera, 2015).

The effects of ICT on access to information had a highly significant positive impact on the use of information and communications technology by extension officers. This implies that a unit change on the effects of ICT on access to information leads to $41.5 \%$ unit change in the use of ICT. This suggests that as the effects of ICT on access to information improve, extension officers' use of ICT also improves. Tanko et al. (2013) reported similar result in a 
Creative Commons User License: CC BY-NC-ND

Abstracted by: EBSCOhost, Electronic Journals Service (EJS), Google Scholar, Journal Seek, Scientific Commons,

Food and Agricultural Organization (FAO), CABI and Scopus
Journal of Agricultural Extension

Vol. 23 (3) July, 2019

ISSN(e): 24086851; ISSN(Print); 1119944X

http://journal.aesonnigeria.org

http://www.ajol.info/index.php/iae Email: editorinchief@aesonnigeria.org

study carried out in Niger State, Nigeria. The authors found a significant positive relationship between the use of ICT tools and age, personal income and availability of ICT facilities, but a negative significant relationship between utilisation and years of experience.

Extension officers' awareness of ICT had a significant positive impact on their use of ICT. This implies that a unit increase in level of awareness leads to $28 \%$ unit increase in the use of ICT. This means that if extension officers are aware of the importance if ICT tools and use them, they will also be able to use them in their professional work. Thus, improving awareness of modern ICT tools may promote their use by both public and private extension officers.

Samansiri and Wanigasundera (2014) also found a correlation between awareness and use of ICT, but no significant relationship between age and use of mobile phones. Tata and McNamara (2016) found that gender, age, education and access to Internet have some impact on challenges in using ICT by extension officers. Similar results were reported by Mabe and Oladele (2012), who found significant determinants of the use of information and communications technology to be educational qualification $(t=-2.29$, $\mathrm{p} \leq 0.05)$; importance of ICT ( $t=-2.02, p \leq 0.05)$; constraints to the use of ICT $(t=8.59, p \leq 0.05)$ and the effects of ICT on access to information ( $\mathrm{t}=4.56, \mathrm{p} \leq 0.05)$. Umar et al. (2015) also discovered that there was a positive correlation and significant relationship between level of training and use of ICTs. The results show a significant statistical relationship between residing within place of work, constraints, age, access to information, awareness of ICTs, type of extension and use of ICTs. 
Creative Commons User License: CC BY-NC-ND

Abstracted by: EBSCOhost, Electronic Journals Service (EJS), Google Scholar, Journal Seek, Scientific Commons,

Food and Agricultural Organization (FAO), CABI and Scopus
Journal of Agricultural Extension

Vol. 23 (3) July, 2019

ISSN(e): 24086851; ISSN(Print); 1119944X

http://journal.aesonnigeria.org

http://www.ajol.info/index.php/jae Email: editorinchief@aesonnigeria.org

Table 2: Determinants of the use of ICTs

\begin{tabular}{|c|c|c|c|c|}
\hline Variables & $B$ & $\begin{array}{l}\text { Standard } \\
\text { Error }\end{array}$ & $\begin{array}{l}\text { Standard } \\
\text { coefficient }\end{array}$ & $\mathrm{T}$ \\
\hline (Constant) & 11.639 & 7.914 & & 1.471 \\
\hline e-readiness & .381 & 246 & .150 & 1.546 \\
\hline Residence & 2.935 & 1.426 & 182 & $2.051^{*}$ \\
\hline Constraints & .412 & 158 & 199 & $2.606^{*}$ \\
\hline Job location & -1.713 & 1.406 & -.097 & -1.218 \\
\hline Means of mobility & 1.138 & .688 & .125 & 1.655 \\
\hline Religion & -.732 & .624 & -.092 & -1.173 \\
\hline Age & -.211 & .072 & -.230 & $-2.931^{*}$ \\
\hline Gender & -.990 & 1.126 & -.068 & -.879 \\
\hline $\begin{array}{l}\text { NO. of groups of farmers } \\
\text { covered }\end{array}$ & .012 & .008 & .122 & 1.467 \\
\hline Access to information & 199 & .040 & .415 & $5.023^{*}$ \\
\hline Importance & .046 & .095 & .059 & .487 \\
\hline Live in job area & 2.573 & 1.630 & 137 & 1.579 \\
\hline Accessibility & .087 & .181 & .093 & .480 \\
\hline Competence & -.197 & .136 & -.205 & -1.447 \\
\hline Awareness & 192 & 102 & 280 & $1.895^{*}$ \\
\hline Availability & -.141 & .193 & -.139 & -.733 \\
\hline Type of extension & -3.207 & 1.710 & -.178 & $-1.876^{\star}$ \\
\hline $\mathrm{F}$ & 7.007 & $\mathrm{P}$ & $.000^{\mathrm{b}}$ & \\
\hline $\mathrm{R}$ & $.760^{\mathrm{a}}$ & R squared & .578 & \\
\hline Adjusted R squared & .495 & & & \\
\hline
\end{tabular}

${ }^{*} \mathbf{P} \leq 0.05$.

\section{Constraints to the Use of ICT}

Table 3 presents results of constraints to the use of information and communications technology as perceived by public and private extension officers in Lesotho. Responses were measured on a 'Yes' (2) and 'No' (1). From the Table, public extension officers considered ten out of 12 statements to be serious constraints. Majority of public officers perceived high cost $(83.7 \%)$, failure of service $(64 \%)$, inability to maintain ICT $(68.6 \%)$, absence of skilled operators (68.6\%), shortage of electricity $(53.5 \%)$, fake and substandard products $(51.2 \%)$, and insufficient service providers in the country $(62.8 \%)$. Other responses were illiteracy $(64 \%)$, poor basic infrastructure $(79.1 \%)$ and non-availability of technical personnel $(72.1 \%)$ as serious constraints to the use of ICT tools. However, high voltage of power supply (62.8\%) and non-availability of genuine parts $(53.5 \%)$ were not serious constraints.

Private extension officers indicated high cost $(73.7 \%)$, failure of service $(73.7 \%)$, inability to maintain ICT $(52.6 \%)$, non-availability of genuine parts $(57.9 \%)$, fake and sub-standard products $(52.6 \%)$, and high voltage of power $(57.9 \%)$, illiteracy $(52.6 \%)$ and poor basic 
Creative Commons User License: CC BY-NC-ND

Abstracted by: EBSCOhost, Electronic Journals Service (EJS), Google Scholar, Journal Seek, Scientific Commons,

Food and Agricultural Organization (FAO), CABI and Scopus
Journal of Agricultural Extension

Vol. 23 (3) July, 2019

ISSN(e): 24086851; ISSN(Print); 1119944X

http://journal.aesonnigeria.org

http://www.ajol.info/index.php/iae

Email: editorinchief@aesonnigeria.org

infrastructure (52.6\%) as serious constraints that affect their use of information and communications technology. However, no skill operator $(68.4 \%)$, fluctuation/shortage of supply of electricity (57.9\%), non-availability of technical personnel (57\%) and insufficient service providers $(52.6 \%)$ were not serious constraints.

Both categories of extension officials perceived high cost of some parts of ICT tools or maintenance as a barrier to their adoption. Similarly, Syiem and Raj (2015) reported lack of confidence in operating ICT tools, erratic power supply, low network connectivity and cost of repair as constraints. Omotesho et al. (2012) also reported a number of challenges that were serious constraints to access of ICTs among Agricultural Extension Officers and Subject Matter Specialists in Kwara State, Nigeria. Their list included high cost of ICT equipment, inadequate electricity supply, weak communication and high cost of the Internet. Other constraints were low economic status and distant location of ICT facilities. Similarly, Mabe (2012) found that constraints faced by extension officers in the North West Province, South Africa included failure of service, poor basic infrastructure that encourages ICT, inability to maintain the ICT, too costly as well as non-availability of technical personnel. There seems to be similar challenges facing African countries in the use of ICT in extension service. This is a call for concern and there is need for quick intervention if the benefits with regard to the use of ICT tools are to be realised.

There were significant differences with regard to constraints in the use of ICT tools between public and private extension officers as follows: no skilful operator $(t=3.07$; lack of technical personnel $\left(t=2.38^{\star *}\right)$; and poor ICT infrastructure $(t=2.10$. These differences show a positive relationship between public and private officers. More public officers perceived lack of skilled operators (68.6\%), lack of technical personnel $(72.1 \%)$ and poor ICT infrastructure $(79.1 \%)$ as serious constraints. This agrees with Kabir (2015) who reported unavailability of electricity, lack of proper knowledge of ICT, insufficient availability of ICT services and lack of training on specific aspects of ICT as major constraints among famers in Iran. 
Creative Commons User License: CC BY-NC-ND

Abstracted by: EBSCOhost, Electronic Journals Service (EJS), Google Scholar, Journal Seek, Scientific Commons,

Food and Agricultural Organization (FAO), CABI and Scopus
Journal of Agricultural Extension

Vol. 23 (3) July, 2019

ISSN(e): 24086851; ISSN(Print); 1119944X

http://journal.aesonnigeria.org

http://www.ajol.info/index.php/iae

Email: editorinchief@aesonnigeria.org

Table 3: Constraints to use of ICT tools

\begin{tabular}{|c|c|c|}
\hline Constraints & Public officers (Yes) $(n=86)$ & $\begin{array}{c}\text { Private officers (Yes) (n } \\
=19)\end{array}$ \\
\hline Too costly & 83.7 & 73.7 \\
\hline Failure of service & 64.0 & 73.7 \\
\hline $\begin{array}{l}\text { Inability to maintain the } \\
\text { ICT }\end{array}$ & 68.6 & 52.6 \\
\hline No skillful operator & 68.6 & 31.6 \\
\hline $\begin{array}{l}\text { Fluctuation/shortage in the } \\
\text { supply of electricity }\end{array}$ & 53.5 & 42.1 \\
\hline $\begin{array}{l}\text { Non-availability of genuine } \\
\text { components and parts }\end{array}$ & 46.5 & 57.9 \\
\hline $\begin{array}{l}\text { Non-availability of } \\
\text { technical personnel }\end{array}$ & 72.1 & 42.1 \\
\hline $\begin{array}{l}\text { Fake and substandard ICT } \\
\text { products in the market }\end{array}$ & 51.2 & 52.6 \\
\hline $\begin{array}{l}\text { High voltage of power } \\
\text { supply }\end{array}$ & 37.2 & 57.9 \\
\hline $\begin{array}{l}\text { Insufficient service } \\
\text { providers in the country }\end{array}$ & 62.8 & 47.4 \\
\hline Illiteracy & 64 & 52.6 \\
\hline $\begin{array}{l}\text { Poor basic infrastructure } \\
\text { that encourages ICTs }\end{array}$ & 79.1 & 52.6 \\
\hline
\end{tabular}

\section{Difference in the Use of ICTs Between Public and Private Extension Officers}

Table 4 presents the results for the t-test used to determine the difference in the use of ICTs between public and private extension officers. Out of nine variables, six showed significant differences in the use of ICTs between public and private officers. The significant differences were: e-readiness $(t=-2.031, p \leq 0.05)$; awareness $(t=-2.143$, $p \leq 0.05)$; availability $(t=-4.658, p \leq 0.05)$; accessibility $(t=-464, p \leq 0.05)$; competence $(t=-$ $3.451, p \leq 0.05)$; and access to information $(t=-3.306, p \leq 0.05)$. All these variables are inversely related to being a public or private extension officer. This implies that private extension officers have higher scores in e-readiness $(\bar{x}=16.89)$, awareness of ICT ( $\bar{x}=$ 67.74), availability $(\bar{x}=49.74)$, accessibility to ICTs $(\bar{x}=50.58)$, competence $(\bar{x}=49.26)$ and access to information $(\bar{x}=70.11)$.

This may be due to the fact that private extension officers work in an environment where they have access to ICT tools. Such access has improved their awareness, made them more competent, e-ready and more aware of the effects of ICTs on access to information. Ayansina et al. (2013) reported similar results with significant differences between benefits 
Creative Commons User License: CC BY-NC-ND

Abstracted by: EBSCOhost, Electronic Journals Service (EJS), Google Scholar, Journal Seek, Scientific Commons,

Food and Agricultural Organization (FAO), CABI and Scopus
Journal of Agricultural Extension

Vol. 23 (3) July, 2019

ISSN(e): 24086851; ISSN(Print); 1119944X

http://journal.aesonnigeria.org

http://www.ajol.info/index.php/iae

Email: editorinchief@aesonnigeria.org

achieved by beneficiaries of public and private extension organisations in South West Nigeria. The authors concluded that beneficiaries under private extension organisations had better achievements in terms of increased quantity of crops produced, farm income, acquisition of skills and improved education compared to their counterparts with public extension organisations.

Similar results were obtained by Ali (2013), in his comparison of public and private sources of information for farmers in Uttar Pradesh, India. Ali revealed that delivery sources of information for the private sector provide significantly better quality information to farming communities compared to delivery systems in the public sector. The author, thus, concluded that the results have far-reaching implications for designing successful information and extension delivery models by the public, private or by collaborative efforts of the public and the private sector for better delivery of extension services. Verma et al., 2014 concluded that public extension officers were more affected by constraints to ICT use than non-government extension officers.

There is a significant statistical difference between public and private extension officers regarding e-readiness, awareness of ICT, availability of ICTs, competence in the use of ICTs and access to information.

Table 4: Difference in the use of ICT tools between public and private extension officers in Lesotho

\begin{tabular}{|c|c|c|c|c|c|c|c|}
\hline & $\begin{array}{c}\text { Type of } \\
\text { Extension }\end{array}$ & $\mathrm{N}$ & Mean & SD & SEM & $\mathrm{T}$ & $\mathrm{df}$ \\
\hline \multirow[t]{2}{*}{ E-readiness } & Public & 86 & 15.33 & 2.58 & 27798 & $-2.031^{*}$ & 24 \\
\hline & Private & 19 & 16.89 & 3.14 & .72101 & & \\
\hline \multirow[t]{2}{*}{ Awareness } & Public & 86 & 62.89 & 10.31 & 1.11158 & $-2.143^{*}$ & 31 \\
\hline & Private & 19 & 67.74 & 8.58 & 1.96734 & & \\
\hline \multirow[t]{2}{*}{ Availability } & Public & 86 & 41.27 & 5.74 & .61855 & $-4.658^{*}$ & 23 \\
\hline & Private & 19 & 49.74 & 7.45 & 1.70969 & & \\
\hline \multirow[t]{2}{*}{ Accessibility } & Public & 86 & 40.61 & 5.73 & .61741 & $-4.64^{*}$ & 21 \\
\hline & Private & 19 & 50.58 & 9.01 & 2.06660 & & \\
\hline \multirow[t]{2}{*}{ Competence } & Public & 86 & 41.05 & 5.51 & .59430 & $-3.451^{*}$ & 20 \\
\hline & Private & 19 & 49.26 & 10.05 & 2.30540 & & \\
\hline \multirow[t]{2}{*}{ Importance } & Public & 86 & 46.74 & 9.01 & .97200 & -1.475 & 28 \\
\hline & Private & 19 & 49.95 & 8.46 & 1.94135 & & \\
\hline \multirow[t]{2}{*}{ Use of ICTs } & Public & 86 & 35.91 & 7.38 & .79544 & .221 & 39 \\
\hline & Private & 19 & 36.21 & 4.88 & 1.12020 & & \\
\hline \multirow[t]{2}{*}{ Constraints } & Public & 86 & 19.57 & 3.47 & .37374 & 1.655 & 32 \\
\hline & Private & 19 & 18.37 & 2.71 & .62225 & & \\
\hline Access to & Public & 86 & 60.29 & 14.69 & 1.58471 & $-3.306^{*}$ & 34 \\
\hline information & Private & 19 & 70.11 & 10.94 & 2.51067 & & \\
\hline
\end{tabular}

${ }^{\star \star \star} \mathrm{P} \leq 0.01,{ }^{* *} \mathrm{P} \leq 0.05,{ }^{*} \mathrm{P} \leq 0.10$ 
Creative Commons User License: CC BY-NC-ND

Abstracted by: EBSCOhost, Electronic Journals Service (EJS), Google Scholar, Journal Seek, Scientific Commons,

Food and Agricultural Organization (FAO), CABI and Scopus
Journal of Agricultural Extension

Vol. 23 (3) July, 2019

ISSN(e): 24086851; ISSN(Print); 1119944X

http://journal.aesonnigeria.org

http://www.ajol.info/index.php/iae

Email: editorinchief@aesonnigeria.org

\section{Conclusion and Recommendations}

Most public officers use ICT tools to obtain information on new technology, preserve farm produce, identify time for planting crops, call attention to extension officers and cultural practices. Private officers use ICT tools to obtain information on improving efficiency of management of new technology and new varieties of crop/seeds.

Several constraints hinder use of ICT tools in extension in Lesotho. Major ones were: high costs; poor basic infrastructure; non-availability of technical personnel; failure of service and non-availability of genuine parts. There are differences between public and private extension officers regarding constraints to the use of ICT tools. High cost in the course of using ICT tools is a major challenge. It can also be concluded that older extension officers in both categories are less likely to use ICT. Furthermore, private extension officers have high level of e-readiness, awareness competence in the use of ICT. Private extension officers also have more access to ICT.

There should be a holistic ICT policy that recognises gender equality for professional female extension officers to have equal opportunities to use ICT tools. There is need for regular training of public and private extension officers in image technology, the use of overhead projectors, extension suite online, the Intranet, computer graphics, cinema and other ICT tools. Such training will improve their competence in the use of ICT tools. In order to reduce constraints with regard to the use of ICT tools, there is need for policy makers to address the problem of high cost of ICT tools by providing them to extension officers as official resources for their job. There should be an improvement in basic ICT infrastructures by rating them as important as road construction and include them in budget. There should be improved training of technical personnel and ensure that service providers of ICT tools are effective and genuine ICT parts are available. 
Creative Commons User License: CC BY-NC-ND

Abstracted by: EBSCOhost, Electronic Journals Service (EJS), Google Scholar, Journal Seek, Scientific Commons,

Food and Agricultural Organization (FAO), CABI and Scopus
Journal of Agricultural Extension

Vol. 23 (3) July, 2019

ISSN(e): 24086851; ISSN(Print); 1119944X

http://journal.aesonnigeria.org

http://www.ajol.info/index.php/iae

Email: editorinchief@aesonnigeria.org

\section{References}

Ajani, E. N. (2014). Promoting the use of Information and Communication Technologies (ICTs) for agricultural transformation in Sub-Saharan Africa: Implications for policy. Journal of Agricultural \& Food Information, 15(1), 42-53.

https://doi.org/10.1080/10496505.2013.858049

Ali J. (2013). Farmers' perspective on quality of Agricultural information delivery: A comparison between public and private sources. J. Agric. Sc. Tech. vol. 15: 685-696.

Ayansina, S. O., Adekunle, O. A., Oyeyinka, R. A. and Ayandiji, A. (2013). Assessment of public and private extension administration in South West Nigeria. Journal of Biology, Agriculture and Health Care, Vol.3 No. 19: 45-49.

Bell, M. (2015). Information and Communication Technologies with agricultural extension and advisory services: ICT powering behaviour change in agricultural extension. MEAS Brief.5-14.

Central Intelligence Agency (2015). www.cia.gov/library/publication/th accessed 5/1/2016.

Central Intelligence Agency (2016). www.cia.gov/library/publication/th accessed 5/3/2017.

Food and Agricultural Organisation (2017). Lesotho and FAO: Building resilience and sustainable food and nutrition security. www.fao.org/3/a-au196e-1.pdf accessed 09/07/17.

International Telecommunication Union (2016). Mobile cellular subscriptions.http://www.itu.int/en/ITUD/Statistics/Pages/stat/default.aspx accessed D 20/12/2016.

International Telecommunication Union (2017). ICT facts and figures https://www.itu.int/en/ITU-D/Statistics/Pages/facts/default.aspx accessed 28/03/2018.

Kabir, K. H. and Roy, D. (2015). Preference of ICT tools by the Upazila agriculture officers for information extension in Bangladesh. agriculture. Forestry and Fisheries, 4(2): 5985.

Lesotho Communication Authority (2017). The state of ICT in Lesotho, commissioned by the Lesotho Communications Authority and the International Telecommunication Union. completed March 2017.

Lesotho Review (2015). An overview of the Kingdom of Lesotho's economy. cc available online www.lesothoreview.com/agriculture-2015php.Wade publications. accessed 23/10/2016.

Mabe, L. K. (2012). Constraints related to use of information communication technologies tools among extension officers in the North-West Province, South Africa. Life Science Journal, 9(3), 1616-1619.

Mabe, L. K. and Oladele, O. I. (2012). Perception of extension officers on the importance and use of information communication technologies in the North-West Province, South Africa. Journal of Food, Agriculture and Environment, 10(3-4), 1379-1381.

Maphephe, J. (2014). Information and communications technology lessons from Lesotho 2007-2013, benchmarking and evaluation towards full implementation of ICT policies and strategies. Computing Information Systems Development Informatics and Allied Research, 5(1):119-130.

Maphephe, J., Balkaran, R \& Thakur.S. (2014). Impact of Information and Communication Technology on direct parliament debates and security of the future laws of mountain 
Creative Commons User License: CC BY-NC-ND

Abstracted by: EBSCOhost, Electronic Journals Service (EJS), Google Scholar, Journal Seek, Scientific Commons,

Food and Agricultural Organization (FAO), CABI and Scopus
Journal of Agricultural Extension

Vol. 23 (3) July, 2019

ISSN(e): 24086851; ISSN(Print); 1119944X

http://journal.aesonnigeria.org

http://www.ajol.info/index.php/jae

Email: editorinchief@aesonnigeria.org

kingdom of Lesotho. Computing Information Systems Development Informatics and Allied Research, 5(3):29-44.

Meera, R and Meera, S. N. (2015). Determinants of ICTs in agricultural extension system Indian Res. J. Ext. Edu. 15 (1), January, 2015.

Omotesho, K. F., Ogunlade, I. O. and Muhammad L. (2012). Assessment of access to information and communication technology among agricultural extension officers in Kwara State, Nigeria. Asian Journal Agriculture and Rural Development Vol. 2, No. 2, pp. 220-225.

Qamar, E. (2014). Overview of Agricultural Extension in Lesotho. Retrieved from https://www.g-fras.org/en/world-wide-extension-study/africa/southernafrca/lesotho.html

Samansiri B. A .D and Wanigasundera W. A. D. P. (2014). Use of Information Communication Technology by extension officers of the Tea Small Holdings Development Authority of Sri Lanka. Tropical Agricultural Research Vol. 25 (4) 460475.

Stork, C., Calandro, E. and Gillwald, A. (2013). Internet going mobile: Internet access and use in 11 African countries. Info 15(5): 34-51.

Syiem, R. \& Raj, S. (2015). Access and usage of ICTs for agriculture and rural development by the tribal farmers in Meghalaya State of North-East India. Journal of Agricultural Informatics (ISSN 2061-862X) 6(3) 24-41. doi: 10.17700/jai.2015.6.3.190 24

Tanko, L., Adeniji, O. B. and Nwachukwu, H. (2013). Evaluation of the access to and utilization of information communication technology (ICT) facilities among extension officers in Shiroro LGA, Niger State, Nigeria. Journal of Agricultural Extension and Rural Development Vol. 5(1), pp. 8-13. Available online at http:// academicjournals.org/JAERD DOI: 10.5897/JAERD11.078 ISSN 2141-2154 @ Academic Journals accessed 20/3/2015.

Tata, J. S. and McNamara, P. E. (2016). Social factors that influence use of ICT in agricultural extension in Southern Africa.Agriculture (Switzerland),

6(2).https://doi.org/10.3390/agriculture6020015 https://doi.org/10.1080/1389224X.2017.1387160

Tuoane, s. (2017). Personal communication.

Umar, S. Musa, M. Olayemi, Y. T. and Sulaiman R. (2015). Awareness of Information and Communication Technology among extension agents in Kaduna State on Nigeria. Journal of Agricultural Extension 19(1) ISSN 24086851 http://dx.doi.org/10.4314.jae.v19i1.6 accessed 10/01/2018

United States Agency for International Development (2013). Using ICT to Enhance Marketing for Small Agricultural Producers. Briefing Paper.

Verma, S.R., Sharma, F.L., Singh, N., Chayal, K. and Meena, N.R. (2014). Constraints and obstacles perceived by extension personnel in application of information and communication technology in agriculture. Agric. Update. 9(3): 279-287.

Worth, S. and Molomo, T. (2016). An Assessment of Lesotho's Agricultural Extension System. Consultancy Report for Food and Agriculture Organisation of The United Nations (FAO). TCP/LES/3501 